\title{
Pengolahan Limbah Pasca Panen Menjadi Pupuk Organik Cair dan Kompos pada Kelompok Tani Akur Kabupaten Rejang Lebong
}

\author{
Ria Nurwidiyani $^{1}$, Ghufira ${ }^{2}$, Devi Ratnawati ${ }^{3}$, Deni Agus Triawan ${ }^{4}$, \\ Siska Mawarti ${ }^{5}$ \\ ${ }^{12345}$ Program Studi Kimia, Fakultas MIPA, Universitas Bengkulu \\ E-mail: rianurwidiyani@unib.ac.id
}

\begin{tabular}{l}
\hline Article History: \\
Received: September 2021 \\
Revised: September 2021 \\
Accepted: Oktober 2021 \\
Available online: \\
Desember 2021
\end{tabular}

Keywords: air cucian beras, kompos,komposter,limbah pasca panen, Pupuk organik cair

\begin{abstract}
Kegiatan pengabdian kepada masyarakat ini bertujuan untuk menyebarluaskan pengetahuan kepada masyarakat dalam memanfaatkan limbah pasca panen sayuran menjadi pupuk organik cair dan kompos melalui pengoptimalan teknologi pengomposan menggunakan air cucian beras sebagai media bakteri. Kegiatan diawali dengan penyampaian informasi terkait proses pembuatan komposter bakteri dengan menggunakan air cucian beras, dilanjutkan dengan praktik pengolahan limbah pasca panen menjadi pupuk organik cair dan kompos serta pengaplikasian pupuk organik cair dan kompos pada tanaman. Bedasarkan hasil evaluasi awal diketahui sebanyak $86 \%$ peserta (anggota Kelompok Tani Akur Dusun Curup Kabupaten Rejang Lebong) masih belum mengetahui teknologi pengomposan limbah pasca panen, 14\% peserta cukup mengetahui, dan $0 \%$ peserta sangat mengetahui. Setelah dilakukan pembinaan dan dilakukan evaluasi akhir diperoleh informasi bahwa seluruh peserta $(100 \%)$ telah memahami teknologi pengomposan limbah pasca panen menggunakan komposter air cuian beras. Berdasarkan hal tersebut dapat disimpulkan bahwa kegiatan ini telah meningkatkan pengetahuan dan keterampilan peserta dalam mengolah limbah pasca panen sayuran menjadi pupuk organik cair dan kompos.
\end{abstract}




\section{Pendahuluan}

Kabupaten Rejang Lebong merupakan daerah penghasil komoditas utama pertanian di provinsi Bengkulu. Komoditas pertanian yang dihasilkan Kabupaten Rejang Lebong yang utama meliputi berbagai jenis tanaman pangan, palawija, dan sayur-mayur menjadi pemasok kebutuhan di sejumlah daerah di Provinsi Sumsel, Bangka Belitung, Jambi hingga ke Lampung. Besarnya komoditi hasil pertanian yang dihasilkan dibarengi dengan adanya limbah pasca panen yang juga melimpah akan tetapi hal tersebut tidak diimbangi dengan sistem pengolahan limbah pasca panen yang memadai. Limbah pasca panen merupakan bagian dari tanaman pertanian yang ada di atas tanah atau bagian pucuk, batang yang tersisa setelah dipanen atau diambil hasil utamanya. Limbah pasca panen pada umumnya dibakar atau hanya ditinggalkan di kebun hingga membusuk tanpa diolah lebih lanjut untuk diambil manfaatnya. Limbah sisa tanaman sayur mayur pasca panen kaya akan serat serta mengandung bahan organik tinggi yang dapat diurai menjadi unsur hara yang diperlukan pertumbuhan tanaman. Limbah pasca panen pertanian yang masih dalam kondisi masih segar serta beragamnya mikroorganisme akan semakin meningkatkan kualitas pupuk organic cair yang dihasilkan (Prasetyawati et al., 2019). Pupuk organik cair yang berasal dari limbah pasca panen sayuran dapat membantu mempertahankan kesuburan dan ekosistem tanah karena mengandung unsur Nitrogen, Phosphor, dan Kalium yang merupakan unsur hara yang sangat diperlukan untuk pertumbuhan tanaman (Wardianti et al., 2018). Pupuk organik cair memiliki kandungan bahan kimia anorganik yang relative rendah (kurang dari 5\%) serta dapat diserap dengan mudah oleh tumbuhan karena wujudnya yang berupa cairan (Sulistyaningsih, 2020). Teknologi pengomposan didasarkan pada proses penguraian bahan organik yang dapat terjadi secara alami. Proses pengomposan dapat berjalan dengan lebih cepat dan efisien dengan penambahan mikroorganisme sebagai bakteri pengompos. Optimalisasi pengomposan dapat dilakukan dengan bantuan bakteri pengompos seperti Promi, Orga Dec, Super Dec, BioPos, EM-4 dan lainnya (Triawan et al., 2020). 
Berdasarkan data BPS Kabupaten Rejang Lebong, selama tahun 2015 terjadi penurunan komoditas hasil pertanian di Kabupaten Rejang Lebong yang meliputi komoditi jagung yang mengalami penurunan sebesar 20,03\% dari tahun sebelumnya (39.225 ton pada tahun 2014 menjadi 31.368 ton pada tahun 2015, ubi kayu turun sebesar 36,68\% (28.353ton pada 2014 menadi 17.953 pada 2015), kacang tanah turun sebesar 22,55\% (2.239 pada tahun 2014 ton menjadi 1.734 ton pada than 2015, begitupun komoditas kacang hijau menurun sebesar 19,09\% (241 ton pada tahun 2014 menjadi 195 ton pada tahun 2015). Adanya penurunan komoditas hasil pertanian tersebut disebabkan oleh beberapa faktor salah satunya penggunaan pupuk anorganik tanpa adanya penambahan pupuk organik atau pengembalian biomassa ke dalam tanah. Penggunaan pupuk anorganik menimbulkan dampak negative pada ekosistem pertanian yaitu adanya pengerasan tanah pertanian, pencemaran tanah oleh zat-zat kimia, serta rusaknya struktur tanah (Surtiningsih et al., 2020). Oleh karena itu pengolahan limbah pasca panen sayuran sangat berpotensi untuk dikembangkan oleh para petani guna memperoleh pupuk organik cair dan kompos untuk mengembalikan kesuburan tanah secara ekonomis. Teknologi pengomposan didasarkan pada proses penguraian bahan organik yang terjadi secara alami.

\section{Metode}

\section{Persiapan}

Tahapan persiapan dilakukan dengan melakukan koordinasi dengan Kelompok Tani Akur Dusun Curup Kabupaten Rejang Lebong dan LPPM untuk menentukan waktu pelaksanaan serta teknis pelaksanaaanya. Sebelum pelaksanaan di lapangan dilakukan diskusi antar anggota pengabdian untuk menentukan pembagian tugas masing-masing anggota pada saat pelaksanaan dan persiapan alat-alat yang akan digunakan.

\section{Penyampaian informasi dan diskusi}

Sebelum melakukan praktik pembuatan pupuk cair dan kompos dari limbah pasca panen, para peserta diberikan informasi terkait teknologi pengomposan menggunakan bakteri. Kegiatan ini dimulai dengan pemaparan 
dan penyampaian informasi tentang teknologi pengolahan limbah pasca panen menjadi pupuk organik. Setelah peserta mamahami teori tentang teknologi pengolahan limbah pasca panen menjadi pupuk organik, kegiatan dilanjutkan dengan pelatihan pembuatan reaktor komposter dan praktek pengolahan limbah pasca panen. Penyampaian informasi diselingi dengan diskusi bersama peserta untuk lebih memperdalam pengetahuan peserta pembinaan.

\section{Praktik pembuatan pupuk organik dari limbah pasca panen}

Untuk pelaksanaan kegiatan ini perlu dipersiapkan alat dan bahan yang dibutuhkan. Alat dan bahan yang digunakan untuk membuat tabung komposter adalah sebagai berikut :

a. Drum atau tong plastik yang mempunyai tutup

b. Pipa pralon diameter 2-4 inci

c. Kasa plastik untuk menutup lubang pipa bagian luar

d. Saringan aluminium

Langkah pembuatan pupuk organik cair melalui beberapa tahapan sebagai berikut :

a. Pembuatan komposter air cucian beras

Komposter air cucian beras dibuat dengan cara mengumpulkan air cucian beras bilasan pertama dalam sebuah wadah. Ke dalam air cucian beras tersebut ditambahkan satu tutup botol EM-4 untuk setiap liter air cucian beras. Kemudian air cucian beras yang sudah ditambah dengan EM-4 didiamkan dalam kondisi tertutup selama kurang lebih 1 bulan atau setelah warna larutan semakin pekat kehitaman, barulah komposter air cucian beras dapat digunakan baik sebagai pupuk langsung ataupun sebagai komposter pembuatan pupuk cair dan kompos. Untuk mempercepat pertumbuhan mikroorganisme dalam air cuian beras dapat ditambahkan gula sebagai makanan untuk pertumbuhan bakteri pengompos.

b. Pencacahan limbah pasca panen sayuran 
Proses pencacahan dilakukan untuk memperkecil ukuran limbah pasca panen sayuran. Hal ini bertujuan agar proses pengomposan dapat berjalan dengan lebih cepat.

c. Pengomposan dalam tabung komposter

Limbah sayuran yang sudah dicacah kemudian dicampur dengan komposter air cucian beras dengan cara disemprot sambil diaduk. Setelah komposter telah disemprotkan secara merata pada limbah sayuran, cacahan tersebut dimasukkan ke dalam tabung pengompos selama kurang lebih 1 bulan hingga kompos dan pupuk organik cair terbentuk. Hal ini ditandai dengan bentuk kompos yang berwarna hitam dan bertekstur gembur. Pada bagian bawah tabung pengompos akan terpisahkan pupuk organik cair yang dapat diambil melalui kran yang terpasang pada tabung komposter. Pupuk organik cair dan kompos siap digunakan. Penggunaan pupuk organik cair dapat dilakukan dengan pengenceran 1:10.

\section{Hasil}

Kegiatan pengabdian kepada masyarakat yang bertajuk pembuatan pupuk organik cair dan kompos dari limbah pasca panen sayuran ini dilaksanakan pada tanggal 28 Agustus 2021 di Dusun Curup Kabupaten Rejang Lebong. Kegiatan ini diikuti oleh Kelompok Tani Akur Dusun Curup Kabupaten Rejang Lebong dan beberapa mahasiswa Universitas Bengkulu sebagai peserta serta tim Pengabdian kepada Masyarakat Universitas Bengkulu sebagai pemateri. Penggunaan pupuk organik pada tanaman merupakan alternatif pengganti pupuk anorganik karena pupuk organik cair mengandung unsur hara makro dan mikro serta mikroorganisme yang berfungsi sebagai perombak bahan organic serta perangsang pertumbuhan tanaman (Tarigan et al., 2020). Sebelum kegiatan dimulai para peserta diminta untuk mengisi lembar evaluasi awal untuk mengetahui sejauh mana pengetahuan masyarakat tentang pupuk organik cair dan kompos yang berasal dari limbah sayuran. Berdasarkan hasil evaluasi awal didapatkan informasi bahwa sebanyak $86 \%$ peserta belum mengetahui apa itu pupuk organic cair dan apakah limbah pasca panen sayuran dapat diolah menjadi 
pupuk organik cair dan kompos (Tabel 1). Sebanyak 14\% peserta cukup mengetahui apa itu pupuk organik cair dan apa saja bahan yang dapat digunakan untuk membuat pupuk organik cair namun belum mengetahui bagaimana cara pengolahan bahan dasar menjadi pupuk organik cair. Seluruh peserta (100\%) belum mengetahui bahwa dalam pembuatan pupuk organik cair dan kompos dapat digunakan mikroorganisme yang dibiakkan dalam air cucian beras. Setelah itu kegiatan dilanjutkan dengan penyampaian materi dan diskusi terkait teknologi pengomposan menggunaan starter air cucian beras. Tim pengabdian kepada masyarakat membagikan pamflet/flyer kepada peserta agar para peserta lebih mudah memahami informasi yang disampaikan (Gambar 1).

Setelah peserta memahami prinsip dasar pembuatan pupuk organik cair dan starter air cuian beras, peserta dibimbing untuk mempraktikkan pengetahuan yang baru saja didapat (Gambar 2). Pada saat kegiatan dilakukan masyarakat dusun setempat baru saja memanen sawi hijau, sehingga bahan yang digunakan merupakan sisa hasil panen tersebut berupa daun-daun sawi yang sudah tua serta sudah menguning, daun-daun yang berlubang sehingga tidak layak jual dan sisa-sisa batang sawi hijau.

Tabel 1. Hasil evaluasi tingkat pemahaman peserta sebelum dan sesudah kegiatan

\begin{tabular}{|c|c|c|c|c|c|c|c|c|c|}
\hline \multirow{3}{*}{ No } & \multirow{3}{*}{ Pertanyaan } & \multicolumn{8}{|c|}{ Tingkat Pengetahuan (\%) } \\
\hline & & \multicolumn{2}{|c|}{ Tidak } & \multicolumn{2}{|c|}{ Cukup } & \multicolumn{2}{|c|}{ Sedang } & \multicolumn{2}{|c|}{ Sangat } \\
\hline & & Pra & Post & Pra & Post & Pra & Post & Pra & Post \\
\hline 1. & $\begin{array}{l}\text { Pegethuan tentang } \\
\text { pupuk organik cair }\end{array}$ & 86 & 0 & 14 & 0 & 0 & 0 & 0 & 100 \\
\hline 2. & $\begin{array}{l}\text { Pengetahuan } \\
\text { limbah pasca panen } \\
\text { dapat diolah } \\
\text { menjadi kompos } \\
\text { dan pupuk organik } \\
\text { cair }\end{array}$ & 86 & 0 & 14 & 0 & 0 & 0 & 0 & 100 \\
\hline 3. & $\begin{array}{lr}\text { Pengetahuan } & \text { cara } \\
\text { pengolahan limbah } \\
\text { pasca } & \text { panen } \\
\text { menjadi } & \text { pupuk } \\
\text { organik cair dan } \\
\text { kompos }\end{array}$ & 100 & 0 & 0 & 0 & 0 & 0 & 0 & 100 \\
\hline
\end{tabular}


Dharma Raflesia

Jurnal Ilmiah Pengembangan dan Penerapan IPTEKS

Vol. 19, No. 02, Desember, 2021, pp. $399-408$

4. Pengetahuan bahwa

air cucian beras

$\begin{array}{lllllllll}\text { dapat digunakan } & 100 & 0 & 0 & 0 & 0 & 0 & 0 & 100\end{array}$

sebagai media

starter

Keterangan $:$ Pra $=$ Sebelum kegiatan, Post $=$ Setelah kegiatan

Limbah pasca panen sawi hijau tersebut kemudin dicacah untuk mengecilkan ukuran agar proses pengomposan dapat berlangsung lebih cepat. Setelah dicacah, bahan tersebut dicampur dengan starter yang sebelumnya sudah dibuat menggunakan air cucian beras dan EM-4secara merata dengan cara disemprot.

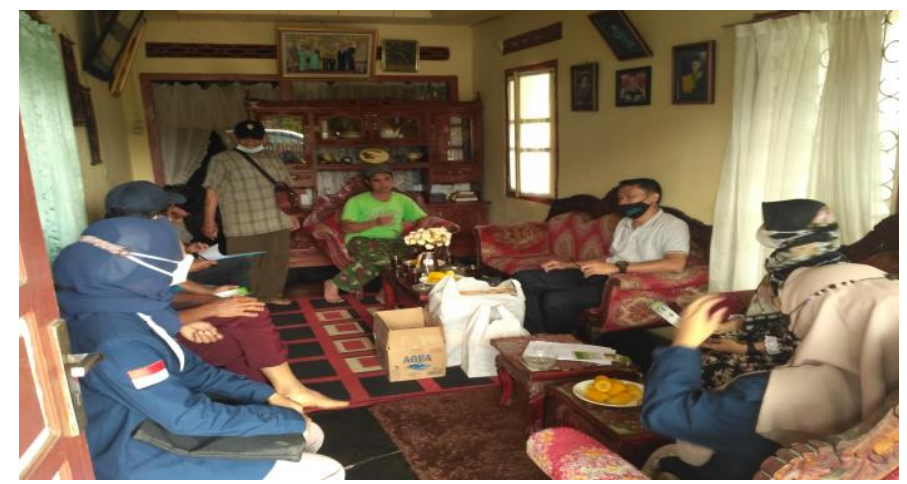

Gambar 1. Proses penyampaian informasi, diskusi dan Tanya jawab

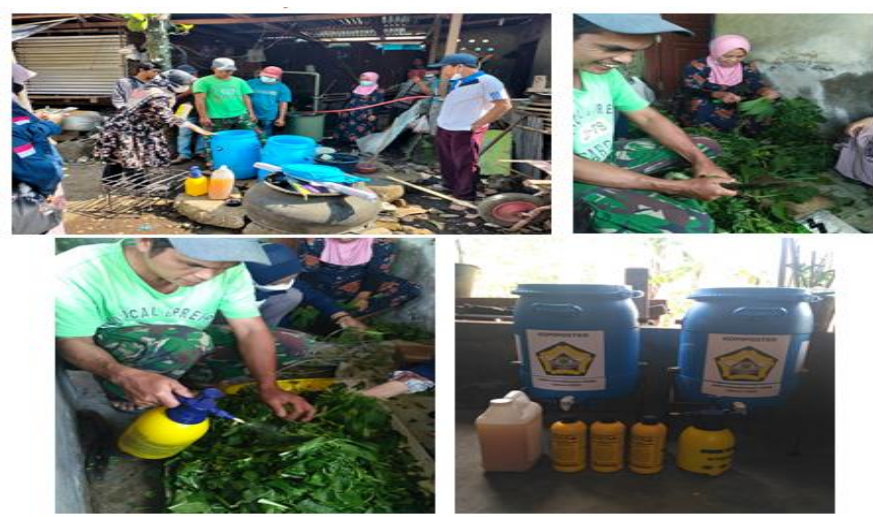

Gambar 2. Praktik Pembuatan Pupuk Organik Cair 
Penggunaan EM-4 dalam pembuatan starter sebagai sumber bakteri dalam proses pengomposan, kandungan mikroorganisme dalam EM-4 akan mempercepat pemecahan nutrisi yang terkandung dalam air cucian beras dan sisa sayuran (Wandhira \& Mulasari, 2013). Untuk mempercepat proses pengomposan maka dapat ditambahkan air gula sebagai bahan makanan bagi bakteri pengompos. Selanjutnya cacahan sisa sayur tersebut dimasukkan ke dalam tabung pengompos tertutup dan difermentasikan selama kurang lebih 1 bulan hingga didapat pupuk organik cair berwarna kecoklatan pada bagian bawah tabung pengompos. Tingkat kematangan pupuk organic cair dapat diketahui dari bau pupuk yang dihasilkan. Pupuk organik cair yang bagus adalah yang tidak berbau busuk (Triyanto \& Maharani, 2019).

Setelah kegiatan praktik terlaksana, dilakukan evaluasi akhir terhadap peserta untuk mengetahui seberapa besar keterserapan pengetahuan yang telah disampaikan. Berdasarkan hasil evaluasi diperoleh data bahwa seluruh peserta $(100 \%)$ sudah sangat mengetahui dan memahami apa itu pupuk organik cair serta bagaimana pengolahanya meggunakan bahan dasar limbah pasa panen sayuran dengan starter air cucian beras.

\section{Diskusi}

Hal yang paling mendasar yang menjadi permasalahan mitra adalah kurangnya informasi yang sampai di masyarakat tentang tentang pengolahan limbah pascapanen menjadi produk yang bernilai guna dan bahkan bernilai ekonomi. Pada dasarnya pupuk organik cair memiliki bermacam keunggulan dibandingkan pupuk kimia. Berdasarkan keguanaannya, pupuk organik cair dapat digunakan untuk meningkatkan produktivitas kedelai (Raksun, 2014), selada (Wenda et al., 2017), jagung (Puspadewi et al., 2016) dan berbagai sayuran lainnya. Penggunaan pupuk organik cair di kalangan petani sayur masih sangat jarang ditemui, padahal menilik dari tersedianya bahan dasar yang melimpah serta keunggulannya, pupuk organik cair dari limbah pascapanen sayuran merupakan solusi bagi pertanian ramah lingkungan di masa depan. Selain itu petani dapat menghemat biaya produksi dengan mengganti penggunaan pupuk anorganik dengan pupuk organik cair ini. Dengan kegiatan pengabdian ini diharapkan dapat menjadi pendorong bagi 
para petani untuk jeli dalam memanfaatkan potensi sumber daya yang dimiliki untuk dapat dimanfaatkan secara lebih maksimal.

\section{Kesimpulan}

Berdasarkan evaluasi kegiatan yang telah dilakukan maka dapat disimpulkan bahwa kegiatan pengabdian kepada masyarakat yaitu pengolahan limbah pasca panen sayuran menjadi pupuk organik cair dan kompos telah berhasil dilakukan. Kegiatan ini telah meningkatkan pengetahuan dan keterampilan peserta (anggota Kelompok Tani Akur Dusun Curup Kabupaten Rejang Lebong) dalam mengolah limbah pasca panen sayuran menjadi pupuk organik cair dan kompos bagi. Selain itu, produk yang dihasilkan dapat dimanfaatkan untuk pemupukan tanaman pertanian sehingga dapat menurunkan biaya produksi.

\section{Acknowledgements}

Penulis mengucapkan terimakasih kepada Universitas Bengkulu atas pendanaan kegiatan pengabdian kepada Masyarakat ini melalui dana PNBP UNIB Tahun 2021 dengan Nomor Kontrak : 2021/UN30.15/AM/2021. Selain itu, ucapan terimakasih juga kami sampaikan kepada Kelompok Tani Akur, Kelurahan Dusun Curup, Kabupaten Rejang Lebong sebagai mitra kegiatan pengabdian ini.

\section{Daftar Referensi}

Prasetyawati, M., Casban, C., Nelfiyanti, N., \& Kosasih, K. (2019). Pelatihan Pembuatan Pupuk Cair Dari Bahan Sampah Organik di RPTRA Kelurahan Penggilingan. Seminar Nasional Pengabdian Masyarakat LPPM UMJ, September 2019, 1-6.

Puspadewi, S., Sutari, W., \& Kusumiyati, K. (2016). Pengaruh Konsentrasi

Pupuk Organik Cair (POC) dan Dosis Pupuk N, P, K terhadap Pertumbuhan dan Hasil Tanaman Jagung Manis (Zea mays L. var Rugosa Bonaf) Kultivar Talenta. Kultivasi, 15(3), 208-216. https://doi.org/10.24198/kultivasi.v15i3.11764

Raksun, A. (2014). Aplikasi Pupuk Organik Cair untuk Meningkatkan Pertumbuhan Kedelai (Glycine max L.). Jurnal Biologi Tropis, 14(1), 62-67. https://doi.org/10.29303/jbt.v14i1.359 
Sulistyaningsih, C. R. (2020). Pemanfaatan Limbah Sayuran, Buah, dan Kotoran Hewan menjadi Pupuk Organik Cair (POC) di Kelompok Tani Rukun Makaryo, Mojogedang Karanganyar. Jurnal Surya Masyarakat, 3(1), 22-31. https://doi.org/10.26714/jsm.3.1.2020.22-31

Surtiningsih, T., Fatimah, F., Ni'matuzahroh, N., Supriyanto, A., \& Nurhariyati, T. (2020). Pelatihan Pembuatan Pupuk Organik Cair Pada

Kelompok Tani Di Kabupaten Probolinggo. Jurnal Layanan Masyarakat (Journal of Public Services), 2(1), 21-24. https://doi.org/10.20473/jlm.v2i1.2018.21-24

Tarigan, S. I., Kapoe, S. K. K. L., Killa, Y. M., Jawang, U. P., \& Nganji, M. U. (2020). Pelatihan Pembuatan Pupuk Organik Cair Berbasis Mikroorganisme Lokal di Desa Tanau Kabupaten Sumba Timur. Sawala : Jurnal Pengabdian Masyarakat Pembangunan Sosial, Desa Dan Masyarakat, 1(2), 78-85. https://doi.org/10.24198/sawala.v1i2.28043

Triawan, D. A., Fitriani, D., \& Nesbah, N. (2020). Pembuatan Pupuk

Organik dari Sampah Rumah Tangga Di Perumahan Bukit Dewa

Residence Kota Bengkulu. Jurnal Dharma Bakti-LPPM IST AKPRIND Yogyakarta, 3(1), 73-79.

Triyanto, Y., \& Maharani, S. (2019). Program Pengabdian Masyarakat Melalui Program Pembuatan Pupuk Organik Cair (POC) dari Bonggol Pisang. Jurnal Pengabdian Masyarakat Ika Bina En Pabolo, 1(1), 10-17. Wandhira, A. A., \& Mulasari, S. A. (2013). Gambaran Percobaan Penambahan EM-4 dan Air Cucian Beras terhadap Kecepatan Proses

Pengomposan. Jurnal Kesehatan Masyarakat, 6(2), 101-112.

Wardianti, Y., Jayati, R. D., \& Fitriyana, N. (2018). Pemasaran dan Manajemen Usaha Pupuk Organik Cair (POC) dari Limbah Sayur. Jurnal Pengabdian Masyarakat, 1(1), 110-122.

Wenda, M., Hidayati, S., \& Purwanti, S. (2017). Aplikasi Pupuk Organik Cair dan Komposisi Media Tanam Terhadap Hasil Tanaman Selada (Lactuca sativa L). Gontor AGROTECH Science Journa, 3(2), 99-118. https://doi.org/10.21111/agrotech. 